\title{
Anti-Inflammatory Activity of A Polyphenolic Extract from Arabidopsis thaliana in In Vitro and In Vivo Models of Alzheimer's Disease
}

\author{
Roberto Mattioli ${ }^{1, *,+(\mathbb{C})}$, Antonio Francioso ${ }^{2,3, *,+}+{ }^{\circ}$, Maria d'Erme ${ }^{2}$, Maurizio Trovato ${ }^{1}(\mathbb{D}$, \\ Patrizia Mancini ${ }^{4}{ }^{(\mathbb{D}}$, Lucia Piacentini ${ }^{1}{ }^{1}$, Assunta Maria Casale ${ }^{1}$, Ludger Wessjohann ${ }^{3}$, \\ Roberta Gazzino ${ }^{1}$ (D), Paolo Costantino ${ }^{1}$ and Luciana Mosca ${ }^{2}$ D \\ 1 Department of Biology and Biotechnology "Charles Darwin”, Sapienza University of Rome, 00185 Roma, \\ Italy; maurizio.trovato@uniroma1.it (M.T.); lucia.piacentini@uniroma1.it (L.P.); \\ assuntamaria.casale@uniroma1.it (A.M.C.); robertagazzino@gmail.com (R.G.); \\ paolo.costantino@uniroma1.it (P.C.) \\ 2 Department of Biochemical Sciences, Sapienza University of Rome, 00185 Roma, Italy; \\ maria.derme@uniroma1.it (M.d.); luciana.mosca@uniroma1.it (L.M.) \\ 3 Department of Bioorganic Chemistry, Leibniz Institute of Plant Biochemistry, 06120 Halle (Saale), Germany; \\ Ludger.Wessjohann@ipb-halle.de \\ 4 Department of Experimental Medicine, Sapienza University of Rome, 00185 Roma, Italy; \\ patrizia.mancini@uniroma1.it \\ * Correspondence: roberto.mattioli@uniroma1.it (R.M.); antonio.francioso@uniroma1.it (A.F.); \\ Tel.: +39-0649910987 (A.F.) \\ + These authors contributed equally to this work.
}

Received: 7 January 2019; Accepted: 3 February 2019; Published: 7 February 2019

check for updates

\begin{abstract}
Alzheimer's disease (AD) is the most common neurodegenerative disorder and the primary form of dementia in the elderly. One of the main features of AD is the increase in amyloid-beta $(\mathrm{A} \beta)$ peptide production and aggregation, leading to oxidative stress, neuroinflammation and neurodegeneration. Polyphenols are well known for their antioxidant, anti-inflammatory and neuroprotective effects and have been proposed as possible therapeutic agents against AD. Here, we investigated the effects of a polyphenolic extract of Arabidopsis thaliana (a plant belonging to the Brassicaceae family) on inflammatory response induced by A $\beta$. BV2 murine microglia cells treated with both $\mathrm{A} \beta_{25-35}$ peptide and extract showed a lower pro-inflammatory (IL-6,IL-1 $\left.\beta, T N F-\alpha\right)$ and a higher anti-inflammatory $(I L-4, I L-10, I L-13)$ cytokine production compared to cells treated with $A \beta$ only. The activation of the Nrf2-antioxidant response element signaling pathway in treated cells resulted in the upregulation of heme oxygenase- $1 \mathrm{mRNA}$ and in an increase of $\mathrm{NAD}(\mathrm{P}) \mathrm{H}$ :quinone oxidoreductase 1 activity. To establish whether the extract is also effective against $A \beta$-induced neurotoxicity in vivo, we evaluated its effect on the impaired climbing ability of AD Drosophila flies expressing human $A \beta_{1-42}$. Arabidopsis extract significantly restored the locomotor activity of these flies, thus confirming its neuroprotective effects also in vivo. These results point to a protective effect of the Arabidopsis extract in $\mathrm{AD}$, and prompt its use as a model in studying the impact of complex mixtures derived from plant-based food on neurodegenerative diseases.
\end{abstract}

Keywords: Arabidopsis thaliana; amyloid beta; polyphenols; Alzheimer's disease; BV2 cells; interleukins; Nrf2; NF- $\mathrm{kB}$

\section{Introduction}

Natural polyphenols, a vast group of compounds present in plant-based food, confers protection against cancer, cardiovascular, metabolic and neurodegenerative diseases [1-4]. 
The interest in polyphenols as possible therapeutic agents in neurodegenerative diseases stems from the well-documented evidence of their antioxidant effects both in vitro and in vivo, as largely studied in Alzheimer's disease (AD) [5]. The complex neuropathology of AD is primarily characterized by increased production of amyloid- $\beta$ (A $\beta$ ) oligomeric species and extracellular deposition of fibrillary $A \beta$ peptides in the form of plaques, whose accumulation is a major cause of inflammation, oxidative stress and mitochondrial dysfunction [6,7]. Among the various neuroprotective strategies against $\mathrm{A} \beta$-mediated reactive oxygen species (ROS) damages and inflammation proposed in $\mathrm{AD}$, polyphenols represent an attractive therapeutic option [8].

Indeed, polyphenols may counteract neurodegenerative diseases with different mechanisms at various levels. They exert antioxidant activity by inducing the expression of antioxidant enzymes, as well as inhibiting the expression of pro-oxidant enzymes [9-11]. By modulating intracellular signaling cascades and gene expression, and by interacting with mitochondria, they induce morphological changes that have a direct positive influence on memory acquisition, consolidation and storage. Moreover, polyphenols exert a remarkable anti-inflammatory activity by suppressing the activation of microglia, and by affecting inflammatory redox signaling pathways via modulation of pro-inflammatory gene expression, mainly acting through nuclear factor-kappaB (NF- $\mathrm{kB}$ ) and mitogen-activated protein kinase signaling $[9,12,13]$. Furthermore, polyphenols may modulate $A \beta$ production and aggregation by stimulating $\alpha$-secretase and by inhibiting $\beta$ - and $\gamma$-secretase, and by competitively interacting with aromatic residues preventing the $\pi-\pi$ interaction, thus blocking the amyloid self-assembly process $[14,15]$. Some phenolics, such as quercetin and myricetin, are able to inhibit the $\beta$-secretase enzyme interfering with the $A \beta$ generation cascade, whereas other phenolics, such as epigallocatechin gallate, curcumin, trans-resveratrol, or oleuropein, are able to inhibit amyloid aggregation and fibrillogenesis [16]. A polyphenol rich extract of Hypericum was suggested to positively affect $A \beta$ clearance by activation of $A B C$ transporters in the blood-brain-barrier [17-19].

Polyphenols have the capacity to influence gene expression by modulating epigenetic mechanisms that have been associated with AD [20]. For instance, resveratrol is an indirect activator of SIRT-1, an $\mathrm{NAD}^{+}$-dependent deacetylase found to be reduced in the cortex of patients with $\mathrm{AD}$, whereas curcumin was shown to inhibit both histone acetyl transferase and DNA methyl transferase-1 [21].

A large body of literature suggests that inflammation is largely mediated by activated microglia in neurodegenerative diseases [22,23]. It has been hypothesized that dietary interventions through the consumption of foods rich in polyphenols and other antioxidants and anti-inflammatory agents may prevent the onset of age-related neurodegenerative diseases [24]. However, in spite of their efficacy, demonstrated by many in vitro studies, single isolated polyphenols have displayed a limited effect in vivo and in clinical trials, mainly due to low bioavailability and scarce solubility $[25,26]$. Conversely, mixed compounds in food sources have unequivocal beneficial effects, and this might be attributed to additive and even synergistic effects among different polyphenols and other food components, such as lipids, sterols, vitamins and minerals. Indeed, there is a growing interest in the importance of assessing the interactions among the various phytochemicals in food, with regard to their effects on the pathophysiology of the human body. However, relatively few studies have yet taken into account the potential protective effects of complex matrices of bioactive molecules contained in foods (for a review see [27]).

Here, we investigated the effects of a polyphenolic extract from the model plant Arabidopsis thaliana on the inflammatory response in BV2 cells treated with $A \beta_{25-35}$ peptide and in an animal model of AD, i.e., Drosophila melanogaster flies expressing human $\mathrm{A} \beta_{1-42}$. Arabidopsis thaliana belongs to the Brassicaceae family and is a model plant widely used in several research fields $[28,29]$. It grows quickly in a growth chamber with computer-controlled crucial parameters-quality/quantity of light, day and night cycles, humidity and temperature-ensuring uniform growth conditions and composition of the juices. Moreover, Arabidopsis has a fully sequenced and extensively mapped genome and metabolome [30,31], as well as a large collection of mutants and genetic/molecular tools 
that make metabolic engineering possible, thus representing an appealing system to study the impact of polyphenolic complex matrices on several human disease models.

\section{Results}

\subsection{Qualitative and Quantitative Analysis of Polyphenols in Arabidopsis Extract}

Several authors reported the presence of flavonoid glycoside derivatives and hydroxycinnamoyl derivatives in Arabidopsis extracts [30,32-34]. To establish the qualitative/quantitative composition of our extract, Arabidopsis seedlings were grown for seven days and the raw juice obtained by cold pressure was analyzed by chromatographic or colorimetric methods. As the raw juice may contain also proteins, minerals, nucleic acids and fibers or chlorophyll that may interfere with polyphenolic determination, the raw juice was extracted with ethyl acetate (EtOAc) in order to obtain a selective enrichment in flavonoids.

Chromatographic analyses of an EtOAc extract of raw juice revealed the presence of polyphenols and flavonoids (Figure 1). Under our chromatographic conditions, the main constituents of the extract were eluted between 4 and $6 \mathrm{~min}$. Main peaks were identified as polyphenols or flavonoids by chromatographic behavior, comparison with analytical standards, UV-visible spectra, molecular mass, molecular formula, and MS/MS fragmentation, and are detailed in Table 1.

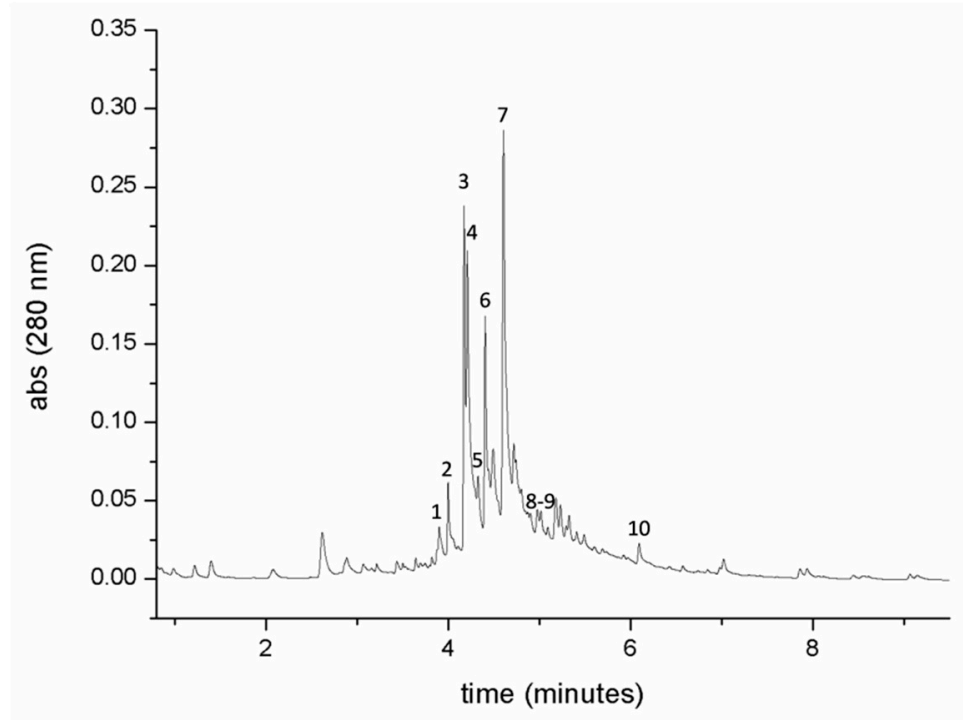

Figure 1. Chromatographic analysis of Arabidopsis thaliana seedlings polyphenols extracted with ethyl acetate from raw juice, registered at $280 \mathrm{~nm}$. Peaks numbered 1-10 are reported in Table 1.

Table 1. Compound identification by combined UPLC-DAD-MS and UHPLC-DAD-HR-MS/MS.

\begin{tabular}{|c|c|c|c|c|c|c|c|c|}
\hline Peak & Compound & $\begin{array}{c}\text { Molecular } \\
\text { Mass } \\
\text { (Calculated) }\end{array}$ & $\begin{array}{l}\text { Molecular } \\
\text { Formula }\end{array}$ & $\begin{array}{c}\lambda \\
\operatorname{Max} \\
(\mathrm{nm})\end{array}$ & $\begin{array}{c}\mathbf{M S}^{1} \\
\text { [M-H] }^{-} \\
\mathbf{m} / \mathbf{z}\end{array}$ & $\begin{array}{c}\mathbf{M S}^{1} \\
{[\mathrm{M}+\mathrm{H}]^{+}} \\
\mathbf{m} / \mathbf{z}\end{array}$ & $\begin{array}{c}\mathrm{MS}^{2} \\
{[\mathrm{M}-\mathrm{H}]^{-} \mathrm{m} / \mathrm{z}}\end{array}$ & $\begin{array}{c}\mathrm{MS}^{2} \\
{[\mathrm{M}+\mathrm{H}]^{+}} \\
\mathbf{m} / \mathbf{z}\end{array}$ \\
\hline $1 *$ & Caffeic acid & 180.06 & $\mathrm{C}_{9} \mathrm{H}_{8} \mathrm{O}_{4}$ & 326 & 179 & & & \\
\hline 2 & Quercetin-rhamnoside-hexoside & 610.16 & $\mathrm{C}_{27} \mathrm{H}_{30} \mathrm{O}_{16}$ & 350 & 609 & 611 & 447,301 & 449,303 \\
\hline 3 & Kaempferol-3-O-glucoside-7-O-rhamnoside & 594.16 & $\mathrm{C}_{27} \mathrm{H}_{30} \mathrm{O}_{1} 5$ & 351 & 593 & 595 & 431,285 & 433,287 \\
\hline 4 & Quercetin-di-rhamnoside & 594.16 & $\mathrm{C}_{27} \mathrm{H}_{30} \mathrm{O}_{15}$ & 350 & 593 & 595 & 447,301 & 449,303 \\
\hline 5 & Isorhamnetin-hexoside-rhamnoside & 624.17 & $\mathrm{C}_{28} \mathrm{H}_{32} \mathrm{O}_{16}$ & 345 & 623 & 625 & 315 & 463,317 \\
\hline 6 & Kaempferol-3, 7-di-O-rhamnoside & 578.17 & $\mathrm{C}_{27} \mathrm{H}_{30} \mathrm{O}_{14}$ & 351 & 577 & 579 & & 433,287 \\
\hline $7^{*}$ & Synapic acid & 224.06 & $\mathrm{C}_{11} \mathrm{H}_{12} \mathrm{O}_{5}$ & 327 & 223 & & & \\
\hline $8-9$ & di-O-sinapoyl- $\beta$-glucose (isomers) & 592.17 & $\mathrm{C}_{28} \mathrm{H}_{32} \mathrm{O}_{14}$ & 327 & 591 & & $367,349,223$ & \\
\hline $10 *$ & Luteolin & 286.05 & $\mathrm{C}_{15} \mathrm{H}_{10} \mathrm{O}_{6}$ & 350 & 285 & 287 & & \\
\hline
\end{tabular}

* confirmed by analytical standard injection. 
Results and experimental data are reported in Table 1. Peak 1 was identified as caffeic acid. Peaks 2-3-4-5 and 6 were identified, respectively, as quercetin-exoside-rhamnoside, kaempferol-3-O-glucoside-7O-rhamnoside, quercetin-dirhamnoside, isorhamnetin-exoside-rhamnoside and kaempferol-3,7-Odirhamnoside. Sinapic acid (peak 7) was identified as the major polyphenolic component of EtOAc extract. Peaks 8 and 9 were identified as two isomers of 1,2-di-synapoyl-D-glucose. Luteolin (peak 10) was one of the last eluted compounds, due to its more hydrophobic nature. All our experimental data reported in Table 1 are in agreement with the known and recent reports in the literature $[35,36]$. For the detailed chemical structures of each compound see Figure S1 supplementary materials.

The total content of polyphenols and anthocyanins was estimated by the Folin-Ciocalteau and $\mathrm{pH}$ differential methods, respectively. The analysis revealed that EtOAc selectively extracts the flavonoidic fraction, while anthocyanins and simple phenolics largely remain in the aqueous layer, as demonstrated by chromatographic analyses (not shown). Total polyphenols, expressed as $\mathrm{mg}$ $\mathrm{GAE} / \mathrm{mL}$, were found to be $0.32 \pm 0.02$ and $0.10 \pm 0.01$ for raw juice and EtOAc extract, respectively; whereas total anthocyanins, expressed as $\mu \mathrm{g}$ CGE $/ \mathrm{mL}$, were $0.88 \pm 0.05$ in raw juice and absent in the EtOAc extract.

In order to verify whether the antioxidant activity was affected by the EtOAc extraction procedure, we performed the 2,2-diphenyl-1-picrylhydrazyl (DPPH) assay on both the raw juice and the extract (see Figure S2 supplementary materials). Data revealed that while in the EtOAc extract the antioxidant activity was linearly related to the amount of extract added, in the raw juice the activity reached a plateau. These results may be justified by the fact that the DPPH assay is performed in ethanol and this solvent may cause the precipitation of proteins and other pigments present in the raw juice that could interfere with spectrophotometric determinations. Based on these observations, all subsequent experiments were performed using the EtOAc extract.

\subsection{The Arabidopsis EtOAc Extract Affects Pro-Inflammatory and Anti-Inflammatory Cytokines Gene Expression in BV2 Cells}

To analyze the inflammatory response, BV2 cells were treated up to $24 \mathrm{~h}$, with $25 \mu \mathrm{M} \mathrm{A} \beta_{25-35}$ aggregated peptide in the presence or absence of the EtOAc extract $(20 \mu \mathrm{L} / \mathrm{mL})$, and the expression of several pro-inflammatory and anti-inflammatory cytokine genes was measured by qRT-PCR. Both the concentration of $A \beta_{25-35}$, as well as the amount of EtOAc extract were chosen based on dose-response curves and on previous data $[37,38]$. The effect of different amounts of Arabidopsis EtOAc extract on BV2 cellular viability was tested up to $50 \mu \mathrm{L} / \mathrm{mL}$ : No cytotoxic effects were observed up to $20 \mu \mathrm{L} / \mathrm{mL}$, whereas higher concentrations caused a slight viability decrease (data not shown). Based on these results, we used a concentration of $20 \mu \mathrm{L} / \mathrm{mL}$ of extract for further experiments.

Figure 2 reports the expression of cytokine genes (IL-6, IL-1 $\beta, T N F-\alpha, I L-4, I L-10, I L-13)$ in control and treated samples at 2 and $24 \mathrm{~h}$. As shown in Figure 2A-C, at 2 hours, IL-6, IL-1 $\beta$ and TNF- $\alpha$ showed overexpression in samples treated with $25 \mu \mathrm{M} \mathrm{A} \beta_{25-35}$ peptide (about 1.5-2 fold), and an even higher expression in samples treated with the EtOAc extract or with both $A \beta_{25-35}$ peptide and EtOAc extract compared to control (about 3-4 fold). The statistical analyses indicate that the overexpression was highly significant, with $p<0.01 \mathrm{vs}$. control for samples treated with $25 \mu \mathrm{M} \mathrm{A} \beta_{25-35}$ peptide and with $p<0.001$ vs. control for samples treated with EtOAc extract or with both $\mathrm{A} \beta_{25-35}$ peptide and EtOAc extract.

After $24 \mathrm{~h}$, pro-inflammatory cytokines gene expression remained steadily high in BV2 cells treated with $A \beta_{25-35}$. Conversely, in cells treated with the EtOAc extract, gene expression reverted to the level of untreated controls, both in the presence and in the absence of $A \beta_{25-35}$. In particular, no significant differences could be observed between controls and samples treated with either the EtOAc extract alone or in the presence of $A \beta_{25-35}$, whereas the treatment with $A \beta_{25-35}$ alone maintained the expression values of all cytokine genes at around 1.5-2 times higher than control, with $p<0.01 \mathrm{vs}$. control. The lower pro-inflammatory cytokine gene expression observed after $24 \mathrm{~h}$ in samples treated with either the EtOAc extract or the extract and $\mathrm{A} \beta_{25-35}$, was already appreciable after six hours (data not shown). 
A

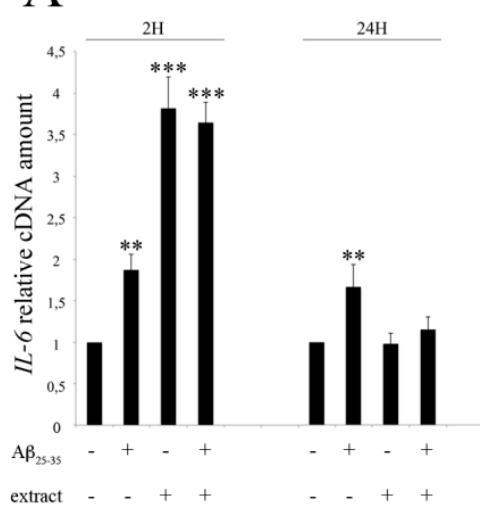

$\mathrm{D}$

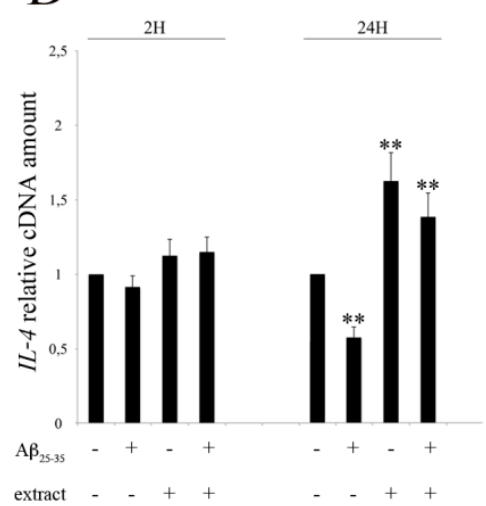

B

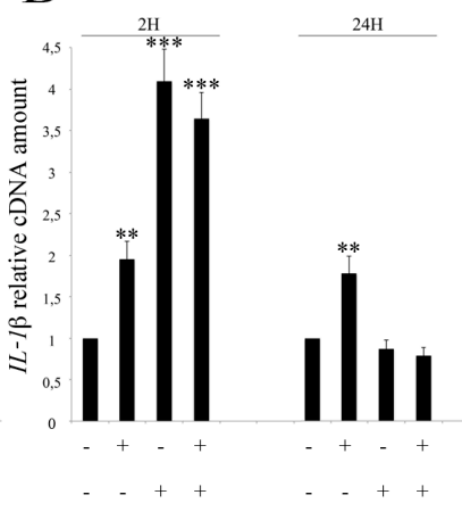

$\mathrm{E}$

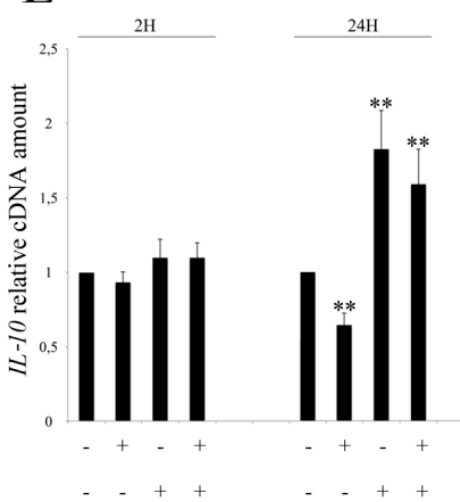

$\mathrm{C}$

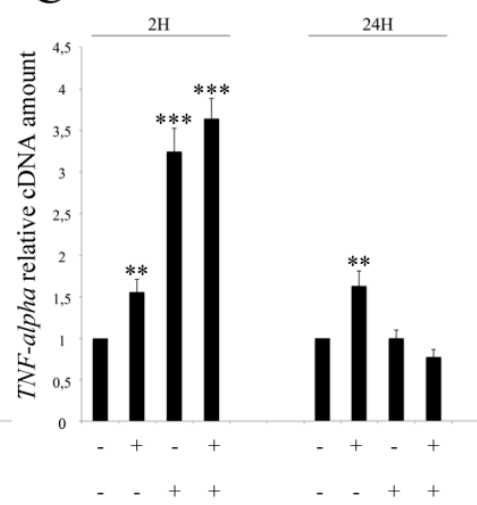

$\mathrm{F}$

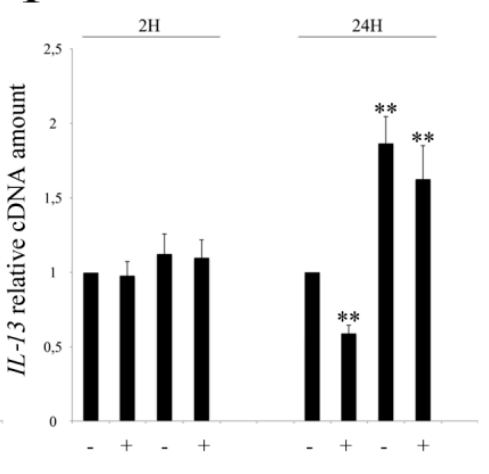

Figure 2. Modulation of pro-inflammatory and anti-inflammatory cytokines in BV2 cells treated with $25 \mu \mathrm{M} \mathrm{A} \beta_{25-35}$ and/or $20 \mu \mathrm{L} / \mathrm{mL}$ of EtOAc extract, evaluated by qRT-PCR at 2 and $24 \mathrm{~h}$. (A) IL-6 expression; (B) $I L-1 \beta$ expression; (C) TNF- $\alpha$ expression; (D) $I L-4$ expression; (E) $I L-10$ expression; (F) IL-13 expression. Data are shown as mean $\pm \operatorname{SEM}(n=3)$. ${ }^{* *} p<0.01$ vs. Ctrl; ${ }^{* * *} p<0.001$ vs. Ctrl.

We also analyzed the anti-inflammatory response, testing the expression of the anti-inflammatory cytokine genes $I L-4, I L-10$ and $I L-13$ (Figure 2C,D,F). After $2 \mathrm{~h}$, no significant differences between control and samples treated with $25 \mu \mathrm{M} \mathrm{A} \beta_{25-35}$ could be evidenced, although there was a slight decrease of gene expression. After $24 \mathrm{~h}$, the treatment with $\mathrm{A} \beta_{25-35}$ peptide gave rise to a significant decrease of gene expression in all genes considered, with values of about 0.6 compared to control $(p<0.01)$. In samples treated with the EtOAc extract, either alone or in the presence of $A \beta_{25-35}$, the expression of anti-inflammatory cytokine genes increased by about 1.5- 2 fold compared to controls at $24 \mathrm{~h}$, while after $2 \mathrm{~h}$ only a non statistically significant increase was evidenced, indicating a positive trend.

\subsection{The Arabidopsis EtOAc Extract Affects Nrf2 and p65 Nuclear Translocation in BV2 Cells}

To elucidate the upstream signaling pathway involved in EtOAc extract-induced upregulation of anti-inflammatory and downregulation of pro-inflammatory cytokine genes, we focused on the activation of Nrf2 (nuclear factor E2-related factor 2) and NF- $\mathrm{kB}$ (nuclear factor kappa-light-chain-enhancer of activated B cells). We investigated the Nrf2 and p65 (a subunit of NF- $\mathrm{kB}$ complex) nuclear translocation by immunofluorescence upon treatment of BV2 cells with the $\mathrm{A} \beta_{25-35}$ peptide, with the EtOAc extract, or both compared to untreated cells (Figure 3A). After $2 \mathrm{~h}$ of incubation, most of the Nrf2 and p65 signal in control samples was localized outside the nucleus, with a nucleus/cytoplasm $(n / c)$ signal ratio of $0.83 \pm 0.09$ for Nrf2 and $0.57 \pm 0.07$ for p65 (Figure 3B). When BV2 cells were treated with $25 \mu \mathrm{M} \mathrm{A} \beta_{25-35}$ peptide, a small fraction of Nrf2 translocated into the nucleus and the $\mathrm{n} / \mathrm{c}$ signal ratio became $1.18 \pm 0.13$. Conversely, the $n / c$ signal ratio of p65 raised from 0.57 to $1.37 \pm 0.25$, indicating a major change in p65 localization and the activation of NF- $\mathrm{kB}$-mediated 
pathways. In cells treated with the EtOAc extract alone or in combination with the $A \beta_{25-35}$ peptide, the nuclear translocation of these proteins was more pronounced: The $\mathrm{n} / \mathrm{c}$ ratio of $\mathrm{Nrf2}$ raised from 0.83 in the control, to $1.94 \pm 0.20$ in the former condition and to $2.02 \pm 0.15$ in the latter; as of p65, the $\mathrm{n} / \mathrm{c}$ raised from 0.57 in control samples to $1.05 \pm 0.07$ and to $1.20 \pm 0.07$ in samples treated with the EtOAc extract alone or in combination with the $A \beta_{25-35}$ peptide, respectively.
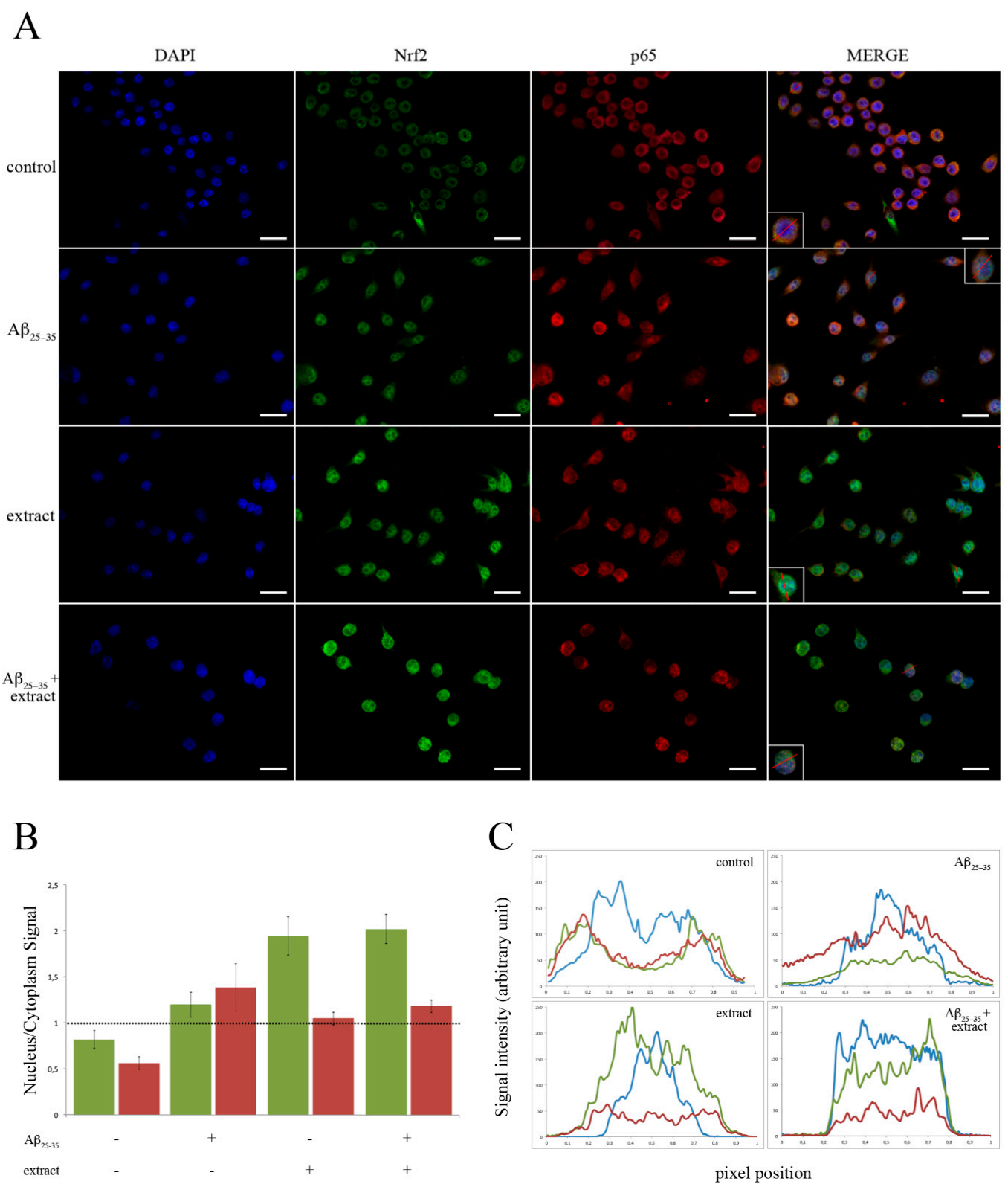

pixel position

Figure 3. Nuclear translocation of Nrf2 and NF- $\kappa$ B. BV2 cells were incubated with $25 \mu \mathrm{M} \mathrm{A} \beta_{25-35}$ in the presence or in the absence of $20 \mu \mathrm{L} / \mathrm{mL}$ of EtOAc extract. (A) Representative images of Nrf2 and NF- $\mathrm{BB}$ nuclear translocation verified by immunofluorescence microscopy by utilizing anti-Nrf2 (green) and anti-p65 (red) antibodies and DAPI staining (blue) (scale bar $=50 \mu \mathrm{m}$ ). (B) Densitometric analysis of the nuclear/cytoplasm signal ratio as calculated by analyzing immunofluorescence images by ImageJ software $(n=50)$. Green bar $=$ Nrf2; Red bar $=$ p65. (C) Analysis by fluorescence staining intensity vs. pixel position of a virtually cut representative cell (The virtual cut is shown by a red line in the insets in panel (A)). Blue line = DAPI; Red line = p65; Green line = Nrf2. 
Analysis by fluorescence staining intensity vs. pixel position showed similar results (Figure 3C). In particular, in control samples the Nrf2 and p65 signal intensity (expressed in arbitrary units-au) was very low in the nucleus (0.2-0.8 pixel range), but was higher than control in samples treated with $\mathrm{A} \beta_{25-35}$, reaching maximum values of 65 au for Nrf2 and 155 au for p65 in the nucleus. Conversely, in cells treated with the EtOAc extract alone or in combination with $\mathrm{A} \beta_{25-35}$, the nuclear translocation of Nrf2 reached maximum values of 250 and 230 au, respectively, whereas p65, was less evident, with maximum values of 50 and 90 au, respectively.

All in all, these data suggest the activation of the NF- $\mathrm{kB}$ pro-inflammatory pathway in samples treated with $\mathrm{A} \beta_{25-35}$ and the activation of Nrf2 anti-inflammatory pathway in samples treated with the EtOAc extract alone or in combination with $\mathrm{A} \beta_{25-35}$.

\subsection{The Arabidopsis EtOAc Extract Affects Cellular Antioxidant Defense Capacity and Counteracts $A \beta_{25-35}$ Induced Cytotoxicity}

It is well known that the activation of the Nrf2 pathway mediates the activation of a set of genes that modulate the antioxidant response of the cell. Among these genes two of the most readily responsive are those encoding the heme oxygenase (HO- 1 ) and the DT-diaphorase (NAD(P)H:quinone oxidoreductase 1, NQO1). To verify whether the nuclear translocation of Nrf2 activates the antioxidant cellular response, we determined the mRNA levels of HO- 1 by qRT-PCR. Moreover, we tested the activity of the enzyme NQO1 by means of a specific spectrophotometric assay. As shown in Figure 4A, in BV2 cells treated with $25 \mu \mathrm{M} \mathrm{A} \beta_{25-35}$ for 2 hours $H O-1$ gene expression showed little change, compared to untreated controls (1.4-fold increase, not statistically significant), while it showed a substantial increase in BV2 cells treated with the EtOAc extract alone or in combination with $\mathrm{A} \beta_{25-35}$ (6.5- and 4.7-fold, respectively; HO-1, $p<0.001$ vs. control).
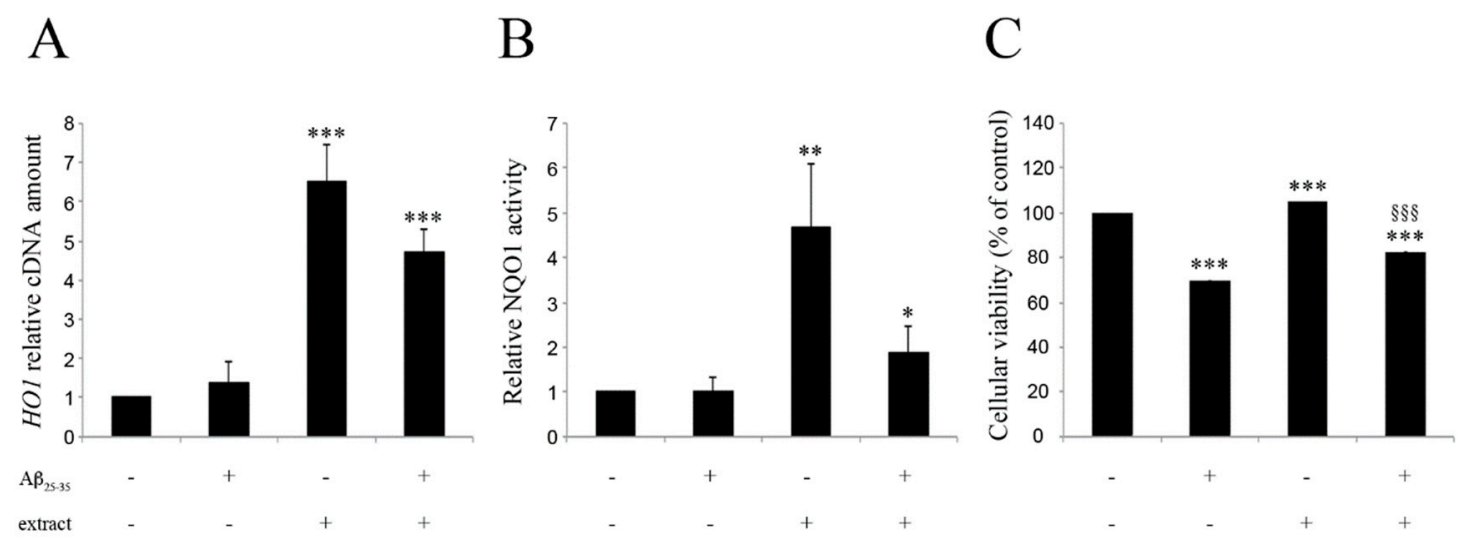

Figure 4. Modulation of HO-1 expression, NQO1 activity and cellular viability of BV2 cells treated with $20 \mu \mathrm{M} \mathrm{A} \beta_{25-35}$ and/or $20 \mu \mathrm{L} / \mathrm{mL}$ of EtOAc extract. (A) HO-1 expression at $2 \mathrm{~h}$. (B) Measurement of NQO1 activity at $24 \mathrm{~h}$. (C) Cellular viability at $24 \mathrm{~h}$ (\% of control). Data are shown as mean \pm SEM $(n=3) .{ }^{*} p<0.05$ vs. Ctrl; ${ }^{* *} p<0.01$ vs. Ctrl; ${ }^{* * *} p<0.001$ vs. Ctrl; $\S \S \S p<0.05$ vs. $\mathrm{A} \beta_{25-35}$.

Measurement of NQO1 activity levels in BV2 cells did not show any effect of $A \beta_{25-35}$ treatment (Figure 4B). Conversely, treatment with the EtOAc extract, either alone or in the presence of $A \beta_{25-35}$, caused a significant increase of the NQO1 activity compared to controls (3.5 and 2 fold, respectively), pointing to an antioxidant effect of the extract.

In order to confirm a cytoprotective effect of the extract, we analyzed the viability of BV2 cells by MTT assay, in the presence of $A \beta_{25-35}$, of EtOAc extract and of both. As shown in Figure $4 C, 25 \mu \mathrm{M}$ $\mathrm{A} \beta_{25-35}$ treatment significantly decreased BV2 cells viability as compared to untreated cells (65\% at $24 \mathrm{~h}, p<0.001$ vs. control), while the treatment with the EtOAc extract alone did not affect cell viability ( $106 \%$ at $24 \mathrm{~h}, p<0.001$ vs. control). Co-treatment with EtOAc extract and $A \beta_{25-35}$ significantly reduced 
$\mathrm{A} \beta_{25-35}$-induced cytotoxicity ( $80 \%$ at $\left.24 \mathrm{~h}, p<0.001 \mathrm{vs.} \mathrm{A} \beta_{25-35}\right)$, pointing to a protective effect of the extract.

\subsection{The Arabidopsis EtOAC Extract Alleviates the Locomotor Dysfunction Induced by $A \beta_{1-42}$ in Drosophila melanogaster}

In order to study the neuroprotective and therapeutic potential of the complex mixtures of polyphenols in vivo, we evaluated the climbing ability of transgenic $A D$ flies expressing human $A \beta_{1-42}$ fed on standard medium supplemented with polyphenolic extract (Figure 5). In our experiments, the glial-specific expression of the human pathogenic construct $\left(\mathrm{A} \beta_{1-42}\right)$ under the control of UAS (Upstream Activator Sequence) elements was achieved by using the pan-glial driver repo-Gal4 [39]. AD flies expressing $A \beta_{1-42}$ were allowed to feed on the diet supplemented with the EtOAc extract ( $40 \mu \mathrm{L} / \mathrm{mL}$ in standard sugar-yeast medium) for the entire developmental period and then assayed for climbing activity at 3-5 and 10-12 days post-eclosion. The results obtained showed that the EtOAc extract significantly ameliorates impaired climbing ability of $A \beta_{1-42}$ flies when compared to untreated control flies, confirming that the Arabidopsis polyphenolic extract exerts a neuroprotective effect also in vivo.

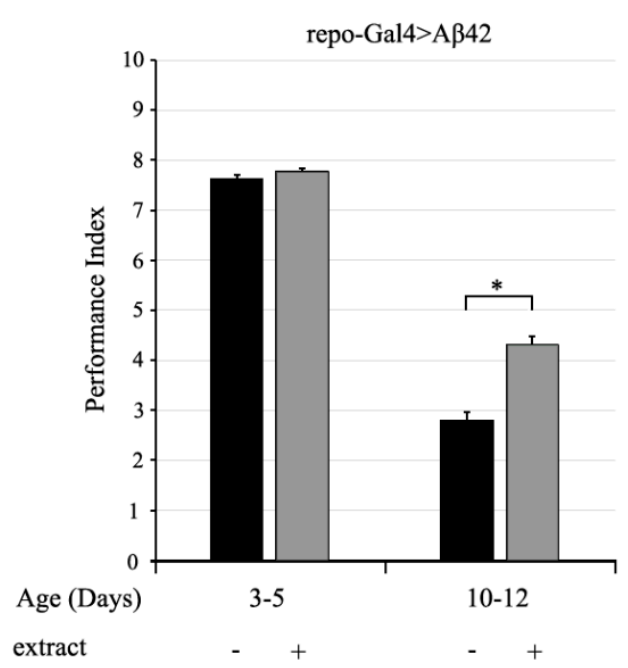

Figure 5. Alzheimer's disease (AD) flies expressing $A \beta_{1-42}$ in glial cells using the repo-Gal4 driver were allowed to feed on the diet supplemented with EtOAc extract $(40 \mu \mathrm{L} / \mathrm{mL}$ in standard sugar-yeast medium) for the entire developmental period and then assayed for climbing activity at 3-5 and 10-12 days. Climbing abilities are presented as the average performance index (PI) $\pm \mathrm{SEM} .{ }^{*} p<0.05$.

\section{Discussion}

The inflammatory response of the brain is mediated by its resident microglia which becomes "activated" when a noxious stimulus hits the brain [22]. Neuroinflammation is initially a protective defense mechanism against injuries or infective agents. In $A D$ brains, $A \beta$ induces increased production of pro-inflammatory cytokines, such as IL- $1 \beta, \mathrm{TNF}-\alpha$ and IL- 6 , which have been demonstrated to cause neuronal toxicity and death [40]. The production of pro-inflammatory cytokines, while having some beneficial effect by ameliorating amyloid deposition, can induce an "autotoxic loop" and enhance tau pathology and neurodegeneration [22]. Based on these observations, it has been proposed that anti-inflammatory drugs may have a therapeutic role in $\mathrm{AD}$. A large body of literature supports the efficacy of NSAIDs in counteracting A $\beta$ toxicity and production, however, clinical trials in AD patients failed to evidence any beneficial effect [23].

The use of polyphenols has been proposed as an alternative valid strategy to dampen inflammatory processes in early $\mathrm{AD}$, and therefore to reduce $\mathrm{AD}$ severity. These natural compounds 
are abundantly present in some foods and, more importantly, food matrices contain mixtures of different polyphenols and flavonoids, which can have additive or even cooperative effects.

Recently, we demonstrated that juices from Brassica oleracea sprouts, containing a complex mixture of polyphenols, are able to protect neuronal cells in culture from the deleterious effects of $A \beta_{25-35}$, through antioxidant mechanisms mediated by the activation of the nuclear factor Nrf2 [41]. The juices derived from edible plants, such as Brassica oleracea, hardly represent the ideal tool to understand how a bioactive compound acts, or how several bioactive molecules interact, in affecting a biological process. Indeed, the domestication of plants resulted in changes to several traits and reduced the genetic variability for several other: In particular healthy bitter components, like many flavonoids or mustard oil components, have been strongly reduced or even eliminated by breeding practices. Most wild plant species, including Arabidopsis thaliana, show a solid intraspecific natural variation for several properties involved in adaptation to different environmental growth conditions (for a review see [42]). Each of the about 7000 wild type Arabidopsis accessions collected and available in the stock center [43] may be characterized by a different polyphenolic profile as suggested by Routaboul et al. [44]. Moreover, Arabidopsis thaliana can be grown in growth chambers under strictly controlled environmental conditions (light, temperature, humidity etc.). As growth conditions do affect the production of secondary metabolites, varying Arabidopsis growth parameters allow to reproducibly modify the polyphenolic content of this plant. Furthermore, the genome of Arabidopsis is completely sequenced and extensively mapped, and a large collection of mutants, as well as a vast arsenal of genetic/molecular tools are available, making metabolic engineering feasible.

Here, we investigated the efficacy of complex polyphenolic mixtures as anti-inflammatory agents in a cellular model of inflammation in AD, i.e., BV2 murine microglial cells stimulated with $A \beta_{25-35}$ in the presence or absence of a polyphenolic extract from Arabidopsis thaliana seedlings.

Polyphenol-containing juice was obtained by cold pressure of seedlings grown for seven days. The choice of this starting material was based on the observation that seedlings usually contain much higher amounts of bioactive and protective compounds per gram of fresh weight than adult plants. Cold pressure was performed to limit auto-oxidation of the phenolic compounds, due to high temperature. Before proceeding to the qualitative analysis of the Arabidopsis extract by UPLC-MS-MS and test them on the cellular and animal models of $\mathrm{AD}$, we enriched the extract in the flavonoidic fraction by extraction with EtOAc. This procedure also allowed us to eliminate proteins, minerals, nucleic acids and fibers or chlorophyll which could affect the interpretation of results. The analysis of phenolics, performed in both raw juices and purified EtOAc extract, revealed the presence of caffeic acid, kaempferol and quercetin derivatives, along with sinapic acid and its derivatives. These results indicate that the Arabidopsis seedling juice has a polyphenolic content similar to that of seeds or of several tissues of adult plants $[30,36]$.

By using this EtOAc extract, we assessed the gene expression profile of pro-inflammatory and anti-inflammatory cytokines following $\mathrm{A} \beta$ treatment in the presence or absence of the EtOAc extract in the short and in the long term. The expression of genes encoding anti-inflammatory cytokines (IL-4, IL-10, IL-13) was downregulated following A $\beta$ treatment, whereas it was upregulated when the phenolic extract was used -either alone or in the presence of $A \beta_{25-35}$, pointing to an action of these compounds against the effects of $A \beta_{25-35}$. Conversely, the expression of pro-inflammatory cytokines $(I L-6, T N F-\alpha, I L-1 \beta)$ increased when the cells were treated with $A \beta_{25-35}$, whereas the effect of the EtOAc extract was less linear. In fact, in the short term the extract seemed to enhance the expression of the cytokines, while in the long term it restored the expression to control levels. Apparently, in the short term the extract is able to activate an inflammatory response which is already reverted at six hours, leading to a suppression of the inflammatory pathway in the long term which contrasts amyloid action. These data may be best interpreted in light of recent evidence which indicates that the production of pro-inflammatory cytokines plays a pivotal role in neurodegeneration, but also in neuroprotection [45]. Indeed, microglia are able to exert either neuroprotective or neurotoxic effects depending on its activation state. Notably, microglia could assume a "classically activated" 
state, termed M1 (a definition borrowed from the activated macrophage states), which is induced by the presence of TNF- $\alpha$ or INF $\gamma$ produced by T-cells or natural killer cells, and displays a high defense profile against pathogens by acidifying the phagosome and releasing ROS/RNS. Conversely, the activation state M2, which results from stimulation of glia by IL-4 and -13, or by IL-10, gives rise to wound healing or anti-inflammatory type microglia. The delicate balance between these two activation states drives the evolution of the neurodegenerative disease. The M1 state is not dangerous per se, but could rather play a defense role in the first phases of the disease. However, if the activation of the M1 state persists and is not replaced by M2 state microglia, the prolonged inflammatory stimulus results in a deleterious effect and tissue damage [46].

The production of cytokines is under the control of a signal transduction circuit involving the Nrf2 and NF- $\mathrm{kB}$ nuclear factors. Nrf2 is a transcription factor that regulates the expression of antioxidant genes that protect against oxidative damage, injury and inflammation by stimulating the anti-inflammatory cytokine genes and antioxidant or phase II detoxification enzymes. This transcription factor is activated by various compounds present in Brassicaceae, such as polyphenols and glucosinolates [47]. Conversely, NF- $\mathrm{BB}$, a protein complex formed by $\mathrm{p} 65$ and p50 subunits, is involved in pro-inflammatory processes and cell death. The stimulation of BV2 cells by A $\beta_{25-35}$, either alone or in combination with the EtOAc extract, causes nuclear translocation of both Nrf2 and NF- $\mathrm{KB}$ p65 subunit within two hours of treatment. In particular, both factors are barely detected at the nuclear level in control cells, whereas under $A \beta_{25-35}$ treatment there is a massive translocation of p65 and a slight translocation of Nrf2. Under polyphenol treatment or co-treatment, Nrf2 translocation is very evident while $\mathrm{p} 65$ is still appreciable. The simultaneous presence of Nrf2 and NF- $\mathrm{kB}$ p 65 in the nucleus when the cells are stimulated with polyphenols, either alone or in the presence of $A \beta_{25-35}$, could be the driving force that stimulates the large expression of the pro-inflammatory cytokines within the short term. According to $[48,49]$, the promoters of pro-inflammatory cytokine genes contain responsive elements for both p65 and Nrf2. However, in the long term the equilibrium is in favor of an anti-inflammatory profile. This shift could be due to an indirect inhibitory effect of Nrf2 on pro-inflammatory cytokines production exerted through the binding to the promoter(s) of alternative genes or to the action of other transcription factors [48].

In short, while in $\mathrm{A} \beta_{25-35}$-treated cells the NF- $\mathrm{BB}$ pro-inflammatory pathway is prevalent, the Nrf2 anti-inflammatory pathway is predominant in cells co-treated with $\mathrm{A} \beta_{25-35}$ and the EtOAc extract or treated with this latter alone. This view is supported by viability data and by the modulation of the expression of genes directly under the control of the Nrf2 pathway, i.e. HO-1 and NQO1. Indeed, cell viability is restored to levels similar to control, and the expression of HO-1 and the activity of NQO1 are positively regulated, when the cells are co-treated or treated with the EtOAc extract, and the expression of $\mathrm{HO}-1$ and the activity of NQO1 is positively regulated, whereas both enzymes remain unaltered when the cells are treated with $\mathrm{A} \beta_{25-35}$ alone.

In order to confirm the efficacy of the extract in vivo, we performed an experiment in an animal model of AD, i.e. Drosophila melanogaster flies expressing the human $\mathrm{A} \beta_{1-42}$ peptide at the glial level. Drosophila offers a powerful in vivo model to study the $A \beta$-induced toxicity, because transgenic expression of the human pathogenic fragment of APP $\left(A \beta_{1-42}\right)$ recapitulates the majority of pathological hallmarks of $\mathrm{AD}$, including neurotoxicity, nuclear inclusion formation, age-dependent neurodegeneration, locomotor dysfunction and early death [50-54]. The Drosophila AD model has been studied to evaluate the protective effects of selected polyphenols as reported in the comprehensive review by Del Rio and Pardo [55]. For instance, beneficial effects of quercetin are mediated by a protein associated with the cell cycle pathway in the Drosophila AD model driving Arctic $A \beta_{1-42}$ expression in the brain [56], whereas Drosophila transgenes fed with curcumin showed a lower $A \beta$ neurotoxicity, due to an acceleration of amyloid fibril conversion [57]. Moreover, AD flies treated with kaempferol showed a delay of climbing ability loss, a rescue of memory and reduced oxidative stress [58]. In our model of transgenic AD flies expressing human $A \beta_{1-42}$, feeding on standard medium supplemented with polyphenolic extract resulted in a significant improvement of the impaired climbing ability of 
AD flies, confirming the neuroprotective effect of the EtOAc extract, also in vivo. These observations also corroborate the notion that in this extract different polyphenols act synergistically and better recapitulate the food content.

\section{Materials and Methods}

\subsection{Chemicals}

Unless otherwise stated, reagents were purchased from Sigma Aldrich (St. Louis, MO, USA). $A \beta_{25-35}$ was synthesized by conventional solid phase chemistry [59]. Other reagents were: Trizol reagent from Invitrogen (Carlsberg, CA, USA); QuantiTect Reverse Transcription kit from QIAGEN (Hilden, Germany); primary antibody rabbit monoclonal anti-Nrf2 and secondary antibody goat polyclonal anti-rabbit IgG (Alexa Fluor ${ }^{\circledR} 488$ ) were from Abcam (Cambridge, UK); mouse monoclonal anti-NFkB p65 subunit was from Cell Signaling Technology (Milan, Italy); and anti-mouse IgG (Texas Red) Jackson Immunoresearch Laboratories (West Grove, PA, USA). Tissue culture medium and serum were from Gibco BRL (Life Technologies Inc., Grand Island, NY, USA)

\subsection{Plant Growth and Juice Preparation}

Wild-type early flowering Arabidopsis thaliana from Columbia-0 (Col-0) ecotype was used in this work. All plants were grown in a growth chamber at $24 / 21^{\circ} \mathrm{C}$ with a light intensity of $300 \mu \mathrm{E} \cdot \mathrm{m}^{-2} \cdot \mathrm{s}^{-1}$ under $16 \mathrm{~h}$ light and $8 \mathrm{~h}$ dark per day. Seeds were surface sterilized with a $2.5 \%$ aqueous solution of INOV'chlore (Inov Chem) for $10 \mathrm{~min}$ and then rinsed four times with sterile water. After five days of cold treatment, Arabidopsis thaliana seeds were plated on one-half MS (Murashige and Skoog medium, Duchefa) and grown in a climate chamber for seven days. The seedlings were collected and cold-pressed for the production of raw juice. The juice obtained was centrifuged at $12,000 \times g$ for $10 \mathrm{~min}$ at $4{ }^{\circ} \mathrm{C}$. The supernatant was immediately frozen in liquid nitrogen and stored at $-80{ }^{\circ} \mathrm{C}$ until use. $2 \mathrm{~mL}$ aliquots were extracted four times with an equal volume of EtOAc. Upper organic phases derived from extractions where combined and divided in 20 aliquots (each corresponding to $100 \mu \mathrm{L}$ of original extract) in $2 \mathrm{~mL}$ propylene microtubes. Vials were then dried under vacuum and each aliquot resuspended in complete culture medium to obtain a final concentration corresponding to $20 \mu \mathrm{L}$ of original extract per $\mathrm{mL}$ of culture medium. Before treating the cells, the diluted extract was filtered on a $0.2 \mu \mathrm{m}$ sterile cellulose acetate membrane.

\subsection{Determination of Total Phenols and Anthocyanins}

Total reductants (mostly phenols) were determined by the Folin-Ciocalteu assay as described by Singleton et al. [60]. Briefly, the reaction solution was prepared by mixing $10 \mu \mathrm{L}$ of blank, standard or sample with $790 \mu \mathrm{L}$ of distilled water. After addition of $50 \mu \mathrm{L}$ Folin-Ciocalteu reagent the reaction mixture was incubated for 3 min at room temperature (RT) and then $150 \mu \mathrm{L}$ of a $20 \%(w / v) \mathrm{Na}_{2} \mathrm{CO}_{3}$ aqueous solution were added. After $2 \mathrm{~h}$ of incubation, the absorbance at $760 \mathrm{~nm}$ was measured on a Hitachi U2000 spectrophotometer (Hitachi, Tokyo, Japan). The results were expressed as mg of gallic acid equivalents (GAE) per $\mathrm{mL}$ of juice.

Total anthocyanins quantification was performed by the $\mathrm{pH}$-differential method as described by Giusti and Wrolstad [61]. The juice was diluted in a pH 1.0 solution $(0.1 \mathrm{M} \mathrm{HCl}, 25 \mathrm{mM} \mathrm{KCl})$ and in a pH 4.5 solution $\left(0.4 \mathrm{M} \mathrm{CH}_{3} \mathrm{COONa}\right)$. The absorbance of the mixtures was then measured at 535 and $700 \mathrm{~nm}$ against distilled water. The value (Abs535 - Abs700)pH 1.0 - (Abs535 - Abs700)pH 4.5 corresponds to the absorbance, due to the anthocyanins. Calculation of the anthocyanin concentration was based on a cyanidin-3-O-glucoside (Cy-3G) molar extinction coefficient of $25,965 \mathrm{M}^{-1} \cdot \mathrm{cm}^{-1}$ and a molecular mass of $449.2 \mathrm{~g} \cdot \mathrm{mol}^{-1}$. Results were expressed as $\mu \mathrm{g}$ cyanidin-3-O-glucoside equivalents (CGE) per $\mathrm{mL}$ of juice. 


\subsection{Chromatography and Mass Spectrometry}

LC-DAD-MS determination of polyphenols was performed on a Waters Acquity H-Class UPLC system (Waters, Milford, MA, USA), including a quaternary solvent manager (QSM), a sample manager with flow through needle system (FTN), a photodiode array detector (PDA) and a single-quadruple mass detector with electrospray ionization source (ACQUITY QDa). Chromatographic analyses were performed on a Waters C18 HSST3 column ( $100 \mathrm{~mm} \times 2.1 \mathrm{~mm}$ i.d., $1.7 \mu \mathrm{m}$ particle size). PDA detector was set up in the range of 200 to $600 \mathrm{~nm}$. Mass spectrometric detection was set in the negative electrospray ionization mode using nitrogen as nebulizer gas. Analyses were performed in Total Ion Current (TIC) mode in a mass range $50-1000 \mathrm{~m} / \mathrm{z}$. Capillary voltage was $0.8 \mathrm{kV}$, cone voltage $30 \mathrm{~V}$, ion source temperature $120^{\circ} \mathrm{C}$ and probe temperature $600{ }^{\circ} \mathrm{C}$.

LC-HR-MS/MS (High Resolution Tandem Mass Spectrometry) measurements were performed on a Dionex Ultimate 3000 UHPLC System, equipped with a quaternary pump, autosampler $(100 \mu \mathrm{L}$ sample loop, partial injection mode, $2 \mu \mathrm{L}$ injection volume, sample temperature $8{ }^{\circ} \mathrm{C}$ ), a photodiode array detector (PDA) (Thermo Fisher Scientific, Bremen, Germany). The effluent from PDA detector was connected on-line to an LTQ-Orbitrap Elite mass spectrometer equipped with a high-temperature electrospray ionization (HESI) ion source, controlled by the Excalibur 2.7 software (Thermo Fisher Scientific, Bremen, Germany) and operated in the negative or positive ion mode. The ion spray voltage was set to $4.0 \mathrm{kV}$, sheath and auxiliary gases on 20 and 5 psi, respectively. The Orbitrap-MS spectra were acquired at the $\mathrm{m} / \mathrm{z}$ range of 50-2000 with a resolution of 30000. The tandem mass spectra were acquired by collision induced dissociation (CID) in linear ion trap (LIT) at $35 \%$ normalized collision energy and isolation width of $2.0 \mathrm{~m} / \mathrm{z}$. The fragments were detected at the FT-resolution of 30000 .

For both LC systems, the same chromatographic method was used. Solvent A was $0.1 \%$ aqueous $\mathrm{HCOOH}$ and solvent $\mathrm{B}$ was $0.1 \% \mathrm{HCOOH}$ in $\mathrm{CH}_{3} \mathrm{CN}$. The flow rate was $0.5 \mathrm{~mL} / \mathrm{min}$ and the column temperature was set at $25{ }^{\circ} \mathrm{C}$. Elution was performed isocratically for the first minute with $2 \% \mathrm{~B}$; from $\min 1$ to min 6 solvent $B$ was linearly increased to $55 \%$; from $\min 6$ to $\min 10$ elution was isocratic with $20 \% \mathrm{~A}$ and $80 \% \mathrm{~B}$; then, in 0.5 min solvent B was set at $100 \%$ and maintained for two minutes. The column was re-equilibrated with $98 \% \mathrm{~A}$ and $2 \% \mathrm{~B}$ before the next injection. An aliquot of the extract dried under vacuum was resuspended in 100 and $10 \mu \mathrm{L}$ injected through the needle. The identity of the compounds of interest was established by using analytical standards and by combining chromatographic behavior, UV-Vis spectral data, mass spectrometric results and mass fragmentation patterns.

\subsection{DPPH Free Radical Scavenging Assay}

An aliquot of $10 \mu \mathrm{L}$ of diluted juices in ethanol $(0-10 \mu \mathrm{L} / \mathrm{mL}$ final concentration) was added to $1 \mathrm{~mL}$ of $30 \mu \mathrm{M}$ ethanolic solution of stable nitrogen centered free radical 2,2-diphenyl-1-picrylhydrazyl $(\mathrm{DPPH} \bullet)$ and the absorbance was monitored spectrophotometrically at $517 \mathrm{~nm}$ after $15 \mathrm{~min}$ at RT. Radical DPPH• scavenging capacity was estimated from the difference in absorbance with or without antioxidants and expressed as percent $\mathrm{DPPH} \bullet$ disappearance as a function of the sample concentration.

\subsection{Preparation of $A \beta_{25-35}$ Stock Solution}

$\mathrm{A} \beta_{25-35}$ was dissolved in sterile phosphate buffered saline, $\mathrm{pH} 7.4$ (PBS) at a concentration of $1 \mathrm{mM}$ and incubated in a sonicator bath on ice for $30 \mathrm{~min}$ to induce aggregation. After treatment, the solution was incubated overnight at $37^{\circ} \mathrm{C}$ and then stored at $-20^{\circ} \mathrm{C}$ until use. Immediately before treating the cells, the stock solution was diluted to $25 \mu \mathrm{M}$ final concentration in culture medium.

\subsection{Cell Culture and Treatment}

BV2 (microglial) cells were a kind gift of Prof. Cinzia Fabrizi. Cells were grown in DMEM/F-12 medium containing 10\% fetal bovine serum (Gibco BRL Life Technologies Inc., Grand Island, NY, USA) and $2 \mathrm{mM} \mathrm{L-glutamine} \mathrm{at} 37^{\circ} \mathrm{C}$ in a humidified atmosphere with $5 \% \mathrm{CO}_{2}$. Cells were plated 
at an appropriate density according to each experimental setting and treated with $25 \mu \mathrm{M}$ aggregated $\mathrm{A} \beta_{25-35}$ in the presence or in the absence of $20 \mu \mathrm{L} / \mathrm{mL}$ of extract reconstituted in DMEM/F12. Cells treated only with EtOAc extract were run in parallel. Untreated cells were used as a control.

\subsection{Cell Viability Assay}

Cell viability was determined by using thiazolyl blue tetrazolium bromide (MTT) dye reduction assay. Briefly, cells were seeded in 96-well plates at a density of 3000 cells/well. After treatment, $20 \mu \mathrm{L}$ of a $5 \mathrm{mg} / \mathrm{mL}$ solution of MTT in PBS was added to the culture medium and cells were incubated at $37^{\circ} \mathrm{C}$ for $2 \mathrm{~h}$. The supernatants were then aspirated off and formazan crystals were dissolved with $100 \mu \mathrm{L} /$ well of dimethyl sulfoxide. The optical density of each well was determined at $570 \mathrm{~nm}$ with a reference at $690 \mathrm{~nm}$ using a microplate reader (Appliskan microplate reader, Thermo Scientific, Vantaa, Finland).

\section{9. $q R T-P C R$}

Total RNA for reverse transcription-polymerase chain reaction (RT-PCR) was extracted using Trizol reagent according to manufacturer's instructions. Reverse transcription was performed from $1 \mu \mathrm{g}$ of total RNA using the QuantiTect Reverse Transcription kit as recommended by the manufacturer. Real-time quantitative RT-PCR (qRT-PCR) measurements were performed using an Applied Biosystems 7300 Real-Time PCR System, using ribosomal protein S27a (RPS27A) housekeeping gene as normalizing control. The genes of which we evaluated expression levels were heme oxygenase-1 (HO-1), interleukin 6 (IL-6), interleukin 1- $\beta(I L-1 \beta)$, TNF- $\alpha(T N F-\alpha)$, interleukin 4 (IL-4), interleukin 10 (IL-10) and interleukin 13 (IL-13). For this purpose, we chose primers designed with GenScript Real-time PCR Primer Design Software and listed in Table 2.

Table 2. Primers used in Real-Time PCR experiments.

\begin{tabular}{|c|c|c|}
\hline \multirow{2}{*}{ Gene } & \multicolumn{2}{|c|}{ Primer Sequence } \\
\hline & FORWARD & REVERSE \\
\hline Heme oxygenase-1 (HO-1) & AGGAGGTACACATCCAAGCC & TACAAGGAAGCCATCACCAG \\
\hline Interleukin $6(I L-6)$ & AAGCTGGAGTCACAGAAGGAG & GGTTTGCCGAGTAGATCTCAA \\
\hline Interleukin $1-\beta(I L-1 \beta)$ & TTCGTGAATGAGCAGACAGC & CCATGGTTTCTTGTGACCCT \\
\hline$T N F-\alpha$ & TGGCCTCTCTACCTTGTTGC & GGGAGCAGAGGTTCAGTGAT \\
\hline Interleukin $4(I L-4)$ & TGTACCAGGAGCCATATCCA & TTCTTCGTTGCTGTGAGGAC \\
\hline Interleukin $10(I L-10)$ & CCCAGAAATCAAGGAGCATT & TCACTCTTCACСТGСТССАС \\
\hline Interleukin $13(I L-13)$ & AGCATGGTATGGAGTGTGGA & TTGCAATTGGAGATGTTGGT \\
\hline Ribosomal protein S27a (RPS27A) & AGAGGCTGATCTTTGCTGGT & ACCAGATGAAGGGTGGACTC \\
\hline
\end{tabular}

The amplifications of qRT-PCR were monitored using the SYBR Green fluorescent stain and the presence of a single PCR product was verified by melting curves in all amplifications. The comparative threshold cycle $\left(\Delta \Delta C_{t}\right)$ method was used to calculate the relative amount of gene expression. The values were normalized with the control and the propagated standard deviations were calculated.

\subsection{NAD(P)H:Quinone Oxidoreductase 1 (NQO1) Activity}

Cells were seeded in $75 \mathrm{~cm}^{2}$ flask at a density of $1.5 \times 10^{6}$ cells/flask. After treatment, the cells were washed with PBS and lysed in $250 \mu \mathrm{L}$ of ice-cold $20 \mathrm{mM}$ Tris-HCl buffer (pH 7.4) containing $250 \mathrm{mM}$ sucrose, $1 \mathrm{mM}$ phenylmethanesulfonyl fluoride and CIP 50×, SigmacOmplete Protease Inhibitor Cocktail by using the Potter-Elvejham homogenizing system. The homogenate was centrifuged at $15,000 \times g$ for $20 \mathrm{~min}$ at $4{ }^{\circ} \mathrm{C}$. NQO1 activity was carried out as previously described [62]. Briefly, the reaction mixture $(1 \mathrm{~mL})$ contained $50 \mathrm{mM}$ sodium phosphate buffer $(\mathrm{pH} 7.4), 0.7 \mathrm{mg} / \mathrm{mL}$ bovine serum albumin (BSA), $40 \mu \mathrm{M}$ 2,6-dichlorophenolindophenol (DCPIP), and $40 \mu \mathrm{g}$ sample proteins. The reaction was started by adding nicotinamide adenine dinucleotide phosphate reduced 
form ( $\beta$-NADPH) at a final concentration of $0.3 \mathrm{mM}$. The decrease in absorbance, due to the reduction of DCPIP, was monitored at $600 \mathrm{~nm}$ during the first $10 \mathrm{~s}$ of the kinetics. Unspecific activity was determined by adding $10 \mu \mathrm{M}$ dicoumarol to the reaction mixture before addition of $\beta$-NADPH and subtracted to total activity. NQO1 activity was calculated as nmol of reduced DCPIP per min per mg of total protein by using an extinction coefficient of $21 \times 10^{-3} \mathrm{M} \times \mathrm{cm}^{-1}$. The intracellular NQO1 activity levels were expressed as a percentage compared to control cells.

\subsection{Nrf2 and NF-кB Immunofluorescence}

Cells were seeded on $18 \times 18 \mathrm{~mm}$ glass coverslips in 6-well plates at a density of $5 \times 10^{5}$ cells/well. After treatment the cells were fixed by incubating with $2 \%(w / v)$ formaldehyde in PBS, washed and permeabilized with $0.1 \%(v / v)$ Triton X-100 in PBS. After washing with PBS, the coverslips were exposed for $30 \mathrm{~min}$ to blocking buffer $\left(5 \%(w / v)\right.$ BSA in PBS) and then incubated overnight at $4{ }^{\circ} \mathrm{C}$ with the rabbit anti-Nrf2 $\mathrm{mAb}$ (1:100 dilution) and with the mouse anti-NF- $\mathrm{kB}$ p65 subunit $\mathrm{mAb}(1: 100$ dilution) in $1 \%(w / v)$ BSA in PBS. The coverslips were washed with PBS before incubation for $1 \mathrm{~h}$ with the secondary antibody Alexa Fluor ${ }^{\circledR} 488$ goat anti-rabbit IgG (1:500 dilution) and with Texas Red goat anti-mouse IgG (1:100 dilution) in 1\% $(w / v)$ BSA in PBS. Nuclei were stained for $1 \mathrm{~min}$ with $1 \mu \mathrm{g} / \mathrm{mL}$ of $4^{\prime}$,6-diamidino-2-phenylindole dihydrochloride (DAPI) in saline solution and the coverslips were mounted with Mowiol. Fluorescence signal was analyzed by recording stained images using an AxioObserver inverted microscope, equipped with the ApoTome System (Carl Zeiss Inc.). Microscopy imaging was performed using the Axiovision software (Zeiss).

To analyze the Nrf2 and NF- $\mathrm{kB}$ nuclear translocation by immunostaining assay, Image software was used, and three fields were analyzed for each sample. The average of signal quantification was obtained by the ratio between mean grey value for each nucleus and cytoplasm after subtraction of background signals, according to:

$$
\sum_{i=1}^{N} \frac{\text { nucleus }-b k}{\frac{\text { cytoplasm-bk }}{N}}
$$

where the nucleus is the mean grey value for each nucleus measured for each nucleus, cytoplasm is the mean grey value measured for each cytoplasm, bk features the mean of background signals and $\mathrm{N}=50$. The errors were calculated as propagated standard deviations.

\subsection{Fly Stocks and Crosses}

Transgenic fly lines that express wild-type human amyloid $\beta 1-42$ (w1118; P\{UAS-APP.A $\beta 42 . B\}$ m26a \#33769) and a pan-glial repo-Gal4 driver (w1118; P\{GAL4\}repo/TM3, Sb1 \#7415) were obtained from Bloomington Drosophila Stock Center (Indiana University, Bloomington, IN). The Ore-R stock used here has been kept in our laboratory for many years.

Briefly, repo-Gal4 virgin females were crossed to Ore-R control flies or A $\beta 42$ flies at $29{ }^{\circ} \mathrm{C}$. The progeny from these crosses were allowed to feed on the diet supplemented with Arabidopsis EtOAc extract $(40 \mu \mathrm{L} / \mathrm{mL}$ in standard sugar-yeast medium) for the entire developmental period. For control food, EtOH alone was added.

\subsection{Climbing Assay}

The climbing assay was performed as described in Feiguin and coworkers [63]. Briefly, a group of 10 flies were placed in an empty vial. A horizontal line was drawn $8 \mathrm{~cm}$ above the bottom of the vial. The number of flies per group that can climb above the $8 \mathrm{~cm}$ mark by 15 seconds after the tap was recorded as the percentage success rate. Ten trials were performed for each group and approximately 100 flies were assayed for each genotype at two time points (at 3-5 days and 10-12 days post-eclosion). All average data are presented as mean \pm SEM and compared with 2-tailed unpaired $t$-tests. Statistical tests were performed using Prism (GraphPad Software, Inc.). All behavioral studies were performed at $25^{\circ} \mathrm{C}$. 


\subsection{Statistical Analysis}

Experiments were repeated at least in triplicate and all the results are expressed as the mean value \pm standard error of the mean (SEM). Statistical comparison between groups was made using unpaired Student's $t$-test. $p$ values $<0.05$ were regarded as significant.

\section{Conclusions}

Our data support the evidence that an Arabidopsis thaliana extract rich in phenolic compounds exert anti-inflammatory activity through the activation of the Nrf2 pathway. This evidence further underlines the importance of correct nutrition as pointed out by epidemiological studies indicating that a diet rich in fruits, vegetables and spices may afford protection against neurodegeneration. Clinical studies employing anti-inflammatory drugs in AD probably failed to succeed, because the treatment was started when the patients already were in an advanced state of the disease. The nutritional approach may circumvent this problem as supplementation with polyphenols may start even at a young age long before disease onset, allowing both prevention and a delay in disease progression, and supporting drug treatment with standard therapeutic approaches. Taken together, our results open the possibility that the Arabidopsis thaliana extract might be useful in the treatment of pathologies that involve chronic inflammation in more complex organisms, such as a mouse, which is one of the most widely used systems to study cellular and molecular bases of human neurodegenerative diseases. Therefore, the anti-inflammatory activity of the polyphenolic extract from Arabidopsis thaliana needs to be explored further in additional in vivo studies to provide a possible strategy to modulate an inflammatory response in the CNS.

Supplementary Materials: Supplementary materials can be found at http:/ /www.mdpi.com/1422-0067/20/3/ $708 /$ s1.

Author Contributions: Conceptualization, R.M., A.F. and L.M.; methodology, R.M., A.F., M.T., P.M., L.P., A.M.C. and L.M.; formal analysis, R.M., A.F., P.M., L.P., A.M.C. and L.M.; resources, M.d., L.W., P.C. and L.M.; writing—original draft preparation, R.M., A.F. and L.M.; writing—review and editing, M.d., M.T., P.M., L.P., A.M.C., L.W., R.G., P.C. and L.M.; supervision, M.d., L.W., P.C. and L.M.; project administration, L.M.; funding acquisition, M.d., P.C. and L.M.

Funding: This work was supported by FILAS-RU-2014-1020, PROS.IT CTN01_00230_413096 and Sapienza Ateneo 2015. A.F. received a FILAS fellowship.

Acknowledgments: The authors would like to thank Bloomington Drosophila Stock Center for kindly providing fly stocks, and Anna Scotto d'Abusco for fruitful discussion. Language editing by Jane Reynolds is gratefully acknowledged.

Conflicts of Interest: The authors declare no conflict of interest.

\section{Abbreviations}

$\mathrm{A} \beta$

$\mathrm{AD}$

DPPH

EtOAc

HO-1

NFKB

NQO1

Nrf2

PBS

ROS
Amyloid beta peptide

Alzheimer's disease

2,2-Diphenyl-1-picrylhydrazyl

Ethyl acetate

Heme Oxygenase 1

Nuclear factor kappa-light-chain-enhancer of activated B cells

NAD(P)H:Quinone oxidoreductase 1

Nuclear factor E2-related factor 2

Phosphate buffer saline

Reactive oxygen species 


\section{References}

1. Scalbert, A.; Manach, C.; Morand, C.; Remesy, C.; Jimenez, L. Dietary polyphenols and the prevention of diseases. Crit. Rev. Food Sci. Nutr. 2005, 45, 287-306. [CrossRef]

2. Graf, B.A.; Milbury, P.E.; Blumberg, J.B. Flavonols, flavones, flavanones, and human health: Epidemiological evidence. J. Med. Food 2005, 8, 281-290. [CrossRef] [PubMed]

3. Arts, I.C.W.; Hollman, P.C.H. Polyphenols and disease risk in epidemiologic studies. Am. J. Clin. Nutr. 2005, 81, 317s-325s. [CrossRef] [PubMed]

4. Pandey, K.B.; Rizvi, S.I. Plant polyphenols as dietary antioxidants in human health and disease. Oxid. Med. Cell. Longev. 2009, 2, 270-278. [CrossRef]

5. Ferrer, I. Defining Alzheimer as a common age-related neurodegenerative process not inevitably leading to dementia. Prog. Neurobiol. 2012, 97, 38-51. [CrossRef] [PubMed]

6. Martire, S.; Fuso, A.; Rotili, D.; Tempera, I.; Giordano, C.; De Zottis, I.; Muzi, A.; Vernole, P.; Graziani, G.; Lococo, E.; et al. PARP-1 Modulates Amyloid Beta Peptide-Induced Neuronal Damage. PLoS ONE 2013, 8 , e72169. [CrossRef] [PubMed]

7. Chen, Z.C.; Zhong, C.J. Oxidative stress in Alzheimer's disease. Neurosci. Bull. 2014, 30, 271-281. [CrossRef]

8. Darvesh, A.S.; Carroll, R.T.; Bishayee, A.; Geldenhuys, W.J.; Van der Schyf, C.J. Oxidative stress and Alzheimer's disease: Dietary polyphenols as potential therapeutic agents. Expert Rev. Neurother. 2010, 10, 729-745. [CrossRef]

9. Jayasena, T.; Poljak, A.; Smythe, G.; Braidy, N.; Munch, G.; Sachdev, P. The role of polyphenols in the modulation of sirtuins and other pathways involved in Alzheimer's disease. Ageing Res. Rev. 2013, 12, 867-883. [CrossRef]

10. Rong, H.; Liang, Y.; Niu, Y. Rosmarinic acid attenuates beta-amyloid-induced oxidative stress via Akt/GSK-3beta/Fyn-mediated Nrf2 activation in PC12 cells. Free Radic. Biol. Med. 2018, 120, 114-123. [CrossRef]

11. Winter, A.N.; Ross, E.K.; Khatter, S.; Miller, K.; Linseman, D.A. Chemical basis for the disparate neuroprotective effects of the anthocyanins, callistephin and kuromanin, against nitrosative stress. Free Radic. Biol. Med. 2017, 103, 23-34. [CrossRef] [PubMed]

12. Vauzour, D.; Rodriguez-Mateos, A.; Corona, G.; Oruna-Concha, M.J.; Spencer, J.P. Polyphenols and human health: Prevention of disease and mechanisms of action. Nutrients 2010, 2, 1106-1131. [CrossRef]

13. Yang, E.J.; Mahmood, U.; Kim, H.; Choi, M.; Choi, Y.; Lee, J.P.; Cho, J.Y.; Hyun, J.W.; Kim, Y.S.; Chang, M.J.; et al. Phloroglucinol ameliorates cognitive impairments by reducing the amyloid beta peptide burden and pro-inflammatory cytokines in the hippocampus of 5XFAD mice. Free Radic. Biol. Med. 2018, 126, 221-234. [CrossRef] [PubMed]

14. Williams, R.J.; Spencer, J.P. Flavonoids, cognition, and dementia: Actions, mechanisms, and potential therapeutic utility for Alzheimer disease. Free Radic. Biol. Med. 2012, 52, 35-45. [CrossRef] [PubMed]

15. Ahmad, E.; Ahmad, A.; Singh, S.; Arshad, M.; Khan, A.H.; Khan, R.H. A mechanistic approach for islet amyloid polypeptide aggregation to develop anti-amyloidogenic agents for type-2 diabetes. Biochime 2011, 93, 793-805. [CrossRef] [PubMed]

16. Francioso, A.; Punzi, P.; Boffi, A.; Lori, C.; Martire, S.; Giordano, C.; D’Erme, M.; Mosca, L. Beta-sheet interfering molecules acting against beta-amyloid aggregation and fibrillogenesis. Bioorgan. Med. Chem. 2015, 23, 1671-1683. [CrossRef]

17. Pahnke, J.; Frohlich, C.; Paarmann, K.; Krohn, M.; Bogdanovic, N.; Arsland, D.; Winblad, B. Cerebral ABC transporter-common mechanisms may modulate neurodegenerative diseases and depression in elderly subjects. Arch. Med. Res. 2014, 45, 738-743. [CrossRef]

18. Brenn, A.; Grube, M.; Jedlitschky, G.; Fischer, A.; Strohmeier, B.; Eiden, M.; Keller, M.; Groschup, M.H.; Vogelgesang, S. St. John's Wort reduces beta-amyloid accumulation in a double transgenic Alzheimer's disease mouse model-role of P-glycoprotein. Brain Pathol. 2014, 24, 18-24. [CrossRef]

19. Hofrichter, J.; Krohn, M.; Schumacher, T.; Lange, C.; Feistel, B.; Walbroel, B.; Pahnke, J. Sideritis spp. Extracts Enhance Memory and Learning in Alzheimer's beta-Amyloidosis Mouse Models and Aged C57Bl/6 Mice. J. Alzheimer's Dis. JAD 2016, 53, 967-980. [CrossRef] 
20. Nicolia, V.; Cavallaro, R.A.; Lopez-Gonzalez, I.; Maccarrone, M.; Scarpa, S.; Ferrer, I.; Fuso, A. DNA Methylation Profiles of Selected Pro-Inflammatory Cytokines in Alzheimer Disease. J. Neuropathol. Exp. Neurol. 2017, 76, 27-31. [CrossRef]

21. Sezgin, Z.; Dincer, Y. Alzheimer's disease and epigenetic diet. Neurochem. Int. 2014, 78, 105-116. [CrossRef] [PubMed]

22. Latta, C.H.; Brothers, H.M.; Wilcock, D.M. Neuroinflammation in Alzheimer's Disease; a Source of Heterogeneity and Target for Personalized Therapy. Neuroscience 2015, 302, 103-111. [CrossRef]

23. Rubio-Perez, J.M.; Morillas-Ruiz, J.M. A Review: Inflammatory Process in Alzheimer's Disease, Role of Cytokines. Sci. World J. 2012. [CrossRef] [PubMed]

24. Engelhart, M.J.; Geerlings, M.I.; Ruitenberg, A.; van Swieten, J.C.; Holman, A.; Witteman, J.C.M.; Breteler, M.M.B. Dietary intake of antioxidants and risk of Alzheimer disease. JAMA-J. Am. Med. Assoc. 2002, 287, 3223-3229. [CrossRef]

25. Ringman, J.M.; Frautschy, S.A.; Teng, E.; Begum, A.N.; Bardens, J.; Beigi, M.; Gylys, K.H.; Badmaev, V.; Heath, D.D.; Apostolova, L.G.; et al. Oral curcumin for Alzheimer's disease: Tolerability and efficacy in a 24-week randomized, double blind, placebo-controlled study. Alzheimers Res. Ther. 2012, 4, 43. [CrossRef] [PubMed]

26. Mazzanti, G.; Di Giacomo, S. Curcumin and Resveratrol in the Management of Cognitive Disorders: What Is the Clinical Evidence? Molecules 2016, 21, 1243. [CrossRef]

27. Omar, S.H.; Scott, C.J.; Hamlin, A.S.; Obied, H.K. The protective role of plant biophenols in mechanisms of Alzheimer's disease. J. Nutr. Biochem. 2017, 47, 1-20. [CrossRef]

28. Biancucci, M.; Mattioli, R.; Moubayidin, L.; Sabatini, S.; Costantino, P.; Trovato, M. Proline affects the size of the root meristematic zone in Arabidopsis. BMC Plant Biol. 2015, 15, 263. [CrossRef]

29. Brunetti, P.; Zanella, L.; De Paolis, A.; Di Litta, D.; Cecchetti, V.; Falasca, G.; Barbieri, M.; Altamura, M.M.; Costantino, P.; Cardarelli, M. Cadmium-inducible expression of the ABC-type transporter AtABCC3 increases phytochelatin-mediated cadmium tolerance in Arabidopsis. J. Exp. Bot. 2015, 66, 3815-3829. [CrossRef]

30. Von Roepenack-Lahaye, E.; Degenkolb, T.; Zerjeski, M.; Franz, M.; Roth, U.; Wessjohann, L.; Schmidt, J.; Scheel, D.; Clemens, S. Profiling of Arabidopsis secondary metabolites by capillary liquid chromatography coupled to electrospray ionization quadrupole time-of-flight mass spectrometry. Plant Physiol. 2004, 134, 548-559. [CrossRef]

31. Beale, M.H.; Sussman, M.R. Metabolomics of Arabidopsis thaliana. In Annual Plant Reviews; Hall, R.D., Ed.; Wiley-Blackwell: Leiden, The Netherlands, 2011; Volume 43, pp. 157-180.

32. Li, J.Y.; Oulee, T.M.; Raba, R.; Amundson, R.G.; Last, R.L. Arabidopsis Flavonoid Mutants Are Hypersensitive to Uv-B Irradiation. Plant Cell 1993, 5, 171-179. [CrossRef] [PubMed]

33. Ryan, K.G.; Swinny, E.E.; Winefield, C.; Markham, K.R. Flavonoids and UV photoprotection in Arabidopsis mutants. Z. Naturforsch. C 2001, 56, 745-754. [CrossRef] [PubMed]

34. Onkokesung, N.; Reichelt, M.; van Doorn, A.; Schuurink, R.C.; van Loon, J.J.A.; Dicke, M. Modulation of flavonoid metabolites in Arabidopsis thaliana through overexpression of the MYB75 transcription factor: Role of kaempferol-3,7-dirhamnoside in resistance to the specialist insect herbivore Pieris brassicae. J. Exp. Bot. 2014, 65, 2203-2217. [CrossRef] [PubMed]

35. Routaboul, J.M.; Kerhoas, L.; Debeaujon, I.; Pourcel, L.; Caboche, M.; Einhorn, J.; Lepiniec, L. Flavonoid diversity and biosynthesis in seed of Arabidopsis thaliana. Planta 2006, 224, 96-107. [CrossRef] [PubMed]

36. Ghura, S.; Tai, L.; Zhao, M.; Collins, N.; Che, C.T.; Warpeha, K.M.; LaDu, M.J. Arabidopsis thaliana extracts optimized for polyphenols production as potential therapeutics for the APOE-modulated neuroinflammation characteristic of Alzheimer's disease in vitro. Sci. Rep. 2016, 6, 29364. [CrossRef] [PubMed]

37. Martire, S.; Fuso, A.; Mosca, L.; Forte, E.; Correani, V.; Fontana, M.; Scarpa, S.; Maras, B.; d’Erme, M. Bioenergetic Impairment in Animal and Cellular Models of Alzheimer's Disease: PARP-1 Inhibition Rescues Metabolic Dysfunctions. J. Alzheimers Dis. 2016, 54, 307-324. [CrossRef] [PubMed]

38. Raha, S.; Lee, H.J.; Yumnam, S.; Hong, G.E.; Saralamma, V.V.G.; Ha, Y.L.; Kim, J.O.; Kim, Y.S.; Heo, J.D.; Lee, S.J.; et al. Vitamin D-2 suppresses amyloid-beta 25-35 induced microglial activation in BV2 cells by blocking the NF-kappa B inflammatory signaling pathway. Life Sci. 2016, 161, 37-44. [CrossRef] [PubMed]

39. Awasaki, T.; Lai, S.L.; Ito, K.; Lee, T. Organization and Postembryonic Development of Glial Cells in the Adult Central Brain of Drosophila. J. Neurosci. 2008, 28, 13742-13753. [CrossRef] [PubMed] 
40. Akiyama, H.; Barger, S.; Barnum, S.; Bradt, B.; Bauer, J.; Cole, G.M.; Cooper, N.R.; Eikelenboom, P.; Emmerling, M.; Fiebich, B.L.; et al. Inflammation and Alzheimer's disease. Neurobiol. Aging 2000, 21, 383-421. [CrossRef]

41. Masci, A.; Mattioli, R.; Costantino, P.; Baima, S.; Morelli, G.; Punzi, P.; Giordano, C.; Pinto, A.; Donini, L.M.; d'Erme, M.; et al. Neuroprotective Effect of Brassica oleracea Sprouts Crude Juice in a Cellular Model of Alzheimer's Disease. Oxid. Med. Cell. Longev. 2015. [CrossRef]

42. Alonso-Blanco, C.; Aarts, M.G.M.; Bentsink, L.; Keurentjes, J.J.B.; Reymond, M.; Vreugdenhil, D.; Koornneef, M. What Has Natural Variation Taught Us about Plant Development, Physiology, and Adaptation? Plant Cell 2009, 21, 1877-1896. [CrossRef] [PubMed]

43. Weigel, D. Natural Variation in Arabidopsis: From Molecular Genetics to Ecological Genomics. Plant Physiol. 2012, 158, 2-22. [CrossRef] [PubMed]

44. Routaboul, J.M.; Dubos, C.; Beck, G.; Marquis, C.; Bidzinski, P.; Loudet, O.; Lepiniec, L. Metabolite profiling and quantitative genetics of natural variation for flavonoids in Arabidopsis. J. Exp. Bot. 2012, 63, 3749-3764. [CrossRef] [PubMed]

45. Wang, W.-Y.; Tan, M.-S.; Yu, J.-T.; Tan, L. Role of pro-inflammatory cytokines released from microglia in Alzheimer's disease. Ann. Transl. Med. 2015, 3, 136.

46. Cherry, J.D.; Olschowka, J.A.; O’Banion, M.K. Neuroinflammation and M2 microglia: The good, the bad, and the inflamed. J. Neuroinflamm. 2014, 11, 98. [CrossRef] [PubMed]

47. Haack, M.; Lowinger, M.; Lippmann, D.; Kipp, A.; Pagnotta, E.; Iori, R.; Monien, B.H.; Glatt, H.; Brauer, M.N.; Wessjohann, L.A.; et al. Breakdown products of neoglucobrassicin inhibit activation of Nrf2 target genes mediated by myrosinase-derived glucoraphanin hydrolysis products. Biol. Chem. 2010, 391, 1281-1293. [CrossRef]

48. Kobayashi, E.H.; Suzuki, T.; Funayama, R.; Nagashima, T.; Hayashi, M.; Sekine, H.; Tanaka, N.; Moriguchi, T.; Motohashi, H.; Nakayama, K.; et al. Nrf2 suppresses macrophage inflammatory response by blocking proinflammatory cytokine transcription. Nat. Commun. 2016, 7, 11624. [CrossRef]

49. Wruck, C.J.; Streetz, K.; Pavic, G.; Gotz, M.E.; Tohidnezhad, M.; Brandenburg, L.-O.; Varoga, D.; Eickelberg, O.; Herdegen, T.; Trautwein, C.; et al. Nrf2 induces interleukin-6 (IL-6) expression via an antioxidant response element within the IL-6 promoter. J. Biol. Chem. 2011, 286, 4493-4499. [CrossRef]

50. Finelli, A.; Kelkar, A.; Song, H.J.; Yang, H.; Konsolaki, M. A model for studying Alzheimer's Abeta42-induced toxicity in Drosophila melanogaster. Mol. Cell. Neurosci. 2004, 26, 365-375. [CrossRef]

51. Crowther, D.C.; Kinghorn, K.J.; Miranda, E.; Page, R.; Curry, J.A.; Duthie, F.A.; Gubb, D.C.; Lomas, D.A. Intraneuronal Abeta, non-amyloid aggregates and neurodegeneration in a Drosophila model of Alzheimer's disease. Neuroscience 2005, 132, 123-135. [CrossRef]

52. Iijima, K.; Iijima-Ando, K. Drosophila models of Alzheimer's amyloidosis: The challenge of dissecting the complex mechanisms of toxicity of amyloid-beta 42. J. Alzheimers Dis. 2008, 15, 523-540. [CrossRef] [PubMed]

53. Prussing, K.; Voigt, A.; Schulz, J.B. Drosophila melanogaster as a model organism for Alzheimer's disease. Mol. Neurodegener. 2013, 8, 35. [CrossRef] [PubMed]

54. Ping, Y.; Hahm, E.T.; Waro, G.; Song, Q.; Vo-Ba, D.A.; Licursi, A.; Bao, H.; Ganoe, L.; Finch, K.; Tsunoda, S. Linking A beta 42-Induced Hyperexcitability to Neurodegeneration, Learning and Motor Deficits, and a Shorter Lifespan in an Alzheimer's Model. PLoS Genet. 2015, 11, e1005025. [CrossRef] [PubMed]

55. Jimenez-Del-Rio, M.; Velez-Pardo, C. Alzheimer's Disease, Drosophila melanogaster and Polyphenols. Adv. Exp. Med. Biol. 2015, 863, 21-53. [PubMed]

56. Kong, Y.; Li, K.; Fu, T.; Wan, C.; Zhang, D.; Song, H.; Zhang, Y.; Liu, N.; Gan, Z.; Yuan, L. Quercetin ameliorates Abeta toxicity in Drosophila AD model by modulating cell cycle-related protein expression. Oncotarget 2016, 7, 67716-67731. [CrossRef]

57. Caesar, I.; Jonson, M.; Nilsson, K.P.; Thor, S.; Hammarstrom, P. Curcumin promotes A-beta fibrillation and reduces neurotoxicity in transgenic Drosophila. PLOS ONE 2012, 7, e31424. [CrossRef] [PubMed]

58. Beg, T.; Jyoti, S.; Naz, F.; Rahul; Ali, F.; Ali, S.K.; Reyad, A.M.; Siddique, Y.H. Protective Effect of Kaempferol on the Transgenic Drosophila Model of Alzheimer's Disease. CNS Neurol. Disord. Drug Targets 2018, 17, 421-429. [CrossRef]

59. Atherton, E.; Sheppard, R.C. Solid Phase Synthesis-A Practical Approach; IRL Press at Oxford University Press: Cary, NC, USA, 1989; p. 203. 
60. Singleton, V.L.; Rossi, J.A., Jr. Colorimetry of Total Phenolics with Phosphomolybdic-Phosphotungstic Acid Reagents. Am. J. Enol. Vitic. 1965, 16, 144-158.

61. Giusti, M.M.; Wrolstad, R.E. Characterization and measurement of anthocyanins by UV-visible spectroscopy. In Current Protocols in Food Analytical Chemistry; Wrolstad, R.E., Schwartz, S.J., Eds.; Wiley: New York, NY, USA, 2001; pp. F1.2.1-F1.2.13.

62. Gaikwad, A.; Long, D.J.; Stringer, J.L.; Jaiswal, A.K. In vivo role of NAD(P)H:quinone oxidoreductase 1 (NQO1) in the regulation of intracellular redox state and accumulation of abdominal adipose tissue. J. Biol. Chem. 2001, 276, 22559-22564. [CrossRef]

63. Feiguin, F.; Godena, V.K.; Romano, G.; D'Ambrogio, A.; Klima, R.; Baralle, F.E. Depletion of TDP-43 affects Drosophila motoneurons terminal synapsis and locomotive behavior. FEBS Lett. 2009, 583, 1586-1592. [CrossRef]

(C) 2019 by the authors. Licensee MDPI, Basel, Switzerland. This article is an open access article distributed under the terms and conditions of the Creative Commons Attribution (CC BY) license (http://creativecommons.org/licenses/by/4.0/). 